\title{
Mental health and art therapy: socio-psychological support of IDPs in the process of adaptation to peaceful life
}

\author{
Yuliia Hundertailo \\ Institute for Social and Political Psychology, National Academy of Educational Sciences of Ukraine, Kyiv, Ukraine
}

\begin{abstract}
The mental health of IDPs in modern Ukraine needs to be maintained both at the macro and micro levels due to the high level of daily stress. The purpose of this study is to unleash the potential of art-therapeutic methods to support IDPs to stabilize their mental state. The methodology of our research is based on theoretical methods of scientific knowledge. The potential of art therapy methods and group forms of work in the process of socially psychological support for IDPs is analyzed. The focus should be on resources available to the community, such as local museums, which can become the material basis for the restoration of social activity of people with disabilities and the spread of stress management practices in everyday life. The biggest limitation of this study is the lack of empirical data on the effects of using art therapy in Ukrainian museums. Among the positive aspects, it should be noted the prospect of improving the mental health of IDPs using art therapy in a museum. As a result, when working with IDPs, we suggest focusing on restoring a sense of security and a sense of belonging to the local population.
\end{abstract}

Introduction. The mental health of IDPs in modern Ukraine needs to be maintained both at the macro and micro levels due to the high level of daily stress. For this group, the population is characterized by the narrowness of social ties and the lack of practices for managing stress in their lives. Specialized art therapy programs can handle these tasks.

Purpose. The purpose of this study is to unleash the potential of art-therapeutic methods to support IDPs to stabilize their mental state.

Design/Methodology/Approach. The methodology of our study is based on theoretical methods for studying factors of improving a person's adaptation, improving his mental health when using art therapeutic methods. Our in-depth analysis aims to build hypotheses about theoretical models for organizing social and psychological support for IDPs

\section{Results.}

The mental health of IDPs needs the focused care of society, as people who leave their permanent place of residence during the war experience numerous stresses and crises, as well as undergo psychological trauma due to the loss of material and human resources and a lack of security. Art-therapeutic methods allow you to express and integrate your own non-verbal and verbal experience; to form an 
internal sense of security; acquire new social connections. Group forms of work in museums with IDPs also contribute to a sense of belonging to local communities and better adaptation to new places of residence.

When developing a model of social and psychological support for IDPs, we took into account the development of technologies for restoring psychological health after a war-related trauma (Titarenko, 2018), and art-therapeutic methods for recovering from psychological trauma. (Hundertaylo Yu, 2019). Thus, to ensure the mental health of IDPs, it is necessary at the micro level - in the host communities - to ensure the implementation of specialized programs of sociopsychological support using art therapeutic methods. The focus should be on resources available to the community, such as local museums, which can become the material basis for the restoration of social activity of people with disabilities and the spread of stress management practices in everyday life. All these actions are aimed at maintaining a stable mental state and psychological health of people who have left their usual places of residence.

Limitations and strengths of the study. The biggest limitation of this study is the lack of empirical data on the effects of using art therapy in Ukrainian museums. Despite this, we see a rather good prospect of studying the impact of specialized programs using art methods on mental health.

Practical/Social value. The social and practical value of steps to organize specialized programs for the social and psychological support of IDPs is to strengthen their mental health.

Originality/Conclusions. When organizing specialized programs of social and psychological support for IDPs, we suggested using the resources of the local community, namely museums. An indicator of the effectiveness of psychological work is the restoration of a sense of security and a sense of belonging to the local population.

\section{References.}

Hundertailo,Yu, Larina, T.O., \& Tytarenko, T.M.,.D., Dvornyk, M.S., Klymchuk, V. O., Lazorenko, B.P., et al. (2019). Sotsial'no-psykholohichni tekhnolohiyi Vidnovlennya zhittyevoyi neperervnosti VPO [Sociopsychological technologies for the restoration of life continuity of IDPs]. Sotsialno-psykhologichni tekhnologiyi vidnovlennya osobystosti pislya travmatychnykh podi: praktychnyj posibnyk - [Sociopsychological technologies of personal recovery after traumatic events: practical guide], (pp. 131-136). Kropyvnytskyi: Imeks-LTD sotsial'no-psykholohichna reabilitatsiya osobystosti: etapy, tekhnolohiyi, tekhniky. [in Ukrainian]

Tytarenko, T.M. (2018). Sotsialno-psykholohichna reabilitatsiya osobystosti: etapy, tekhnolohiyi, tekhniky [Socio-psychological rehabilitation of personality: stages, technologies, techniques.in Ukrainian]. Naukovi studiyi iz sotsial'noyi ta politychnoyi psykholohiyi 41(44), 157-167. [in Ukrainian].

1. Keywords: mental health, art therapy, socio-psychological support, adaptation 